\title{
EFFECT OF DIFFERENT DRYING METHODS ON SOME PROPERTIES OF DRIED OKRA
}

\author{
Keshek, M. H*; and Taha, A.T ${ }^{* *}$ Sobhy, M.M**
}

\section{ABSTRACT}

The aim of this work is to study the effect of drying air temperature in oven dryer and solar drying systems on the physical and mechanical properties of okra pods. Experiments were conducted at 40, 50, 60, 70 and $80{ }^{\circ} \mathrm{C}$ for oven dryer, meanwhile, solar drying systems were conducted at direct dryer with solar collector (D.C), direct dryer without solar collector (D), indirect solar dryer (IN.D) and glass cabinet dryer $(G)$. The drying characteristics and the quality aspects of the dried okra pods were study.

Results indicated that:

-The lower drying time was 12 hours, by oven dryer at $80{ }^{\circ} \mathrm{C}$ for the treated okra pods.

-The lower total color changes $(\Delta E)$ for okra pods were 7.5 and 8.5 under the indirect solar dryer and oven dryer, respectively.

-The higher total color changes $(\Delta E)$ of okra pods were 33.4 and 31.2 under the indirect solar dryer at treated okra pods, and oven dryer at $80^{\circ} \mathrm{C}$, respectively.

-The lower Firmness was $2.67 \mathrm{~kg} / \mathrm{cm}^{2}$, when using the oven dryer at 40 ${ }^{o} \mathrm{C}$ untreated okra pods. The highest Firmness were $5.94 \mathrm{~kg} / \mathrm{cm}^{2}$, for the treated okra pods.

Keywords: Okra, Color, Firmness, Solar, Drying.

\section{1- INTRODUCTION}

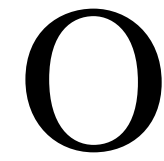
kra probably originates is east African, quite possibly in Ethiopia. It is widely grown in all the regions of the world with a tropical or Mediterranean climate for its immature pods. It grows best in hot weather (temperatures above $26^{\circ} \mathrm{C}$ ). Nowadays, the most important okra-producing countries are India, Nigeria, Pakistan, Ghana and Egypt (FAO, 2003).

\footnotetext{
* Lect. of Agric. Eng. Dep., Fac. of Agr., Men. Univ

**Asso. Prof. of Agric. Eng. Dep., Fac. of Agr., Men. Univ.

*** Postgraduate student Agric. Eng. Dep., Fac. of Agr., Men. Univ.
} 
Nowadays, the most important okra producing countries are India, Nigeria, Pakistan, Ghana, and Egypt. Okra is highly perishable because of its high moisture content and respiratory activities; thus, it is necessary to preserve the commodity. The traditional method for preserving okra involves slicing and sun drying of the fruits until they become brittle (Kolawole and Bukola, 2010).

Fresh harvested okra has very high moisture content $(88-90 \%$ wet basis) with safe moisture content for storage (10\% wet basis) (Shivhare et al., 2000).

Okra traditionally preserved by drying on various surfaces such as the ground, racks, trays and concrete floors. Although sun drying is the most common method used to preserve agricultural products in tropical and sub-tropical countries, this technique is extremely weather dependent, and has the problem of contamination with foreign matter. In addition, the required drying time can be quite long and the sensory qualities of the final product can deteriorate. Therefore, an effective means of overcoming these problems is to dry the okra and other vegetables with solar and hot air dryers. Therefore, an effective means of overcoming these problems is to dry okra with solar or hot air driers (Doymaz and Pala, 2002).

Okra consumed as a fresh vegetable, a cooked vegetable or as an additive for soups, salads and stews. It provides some amount of vitamins, dietary fiber, energy and minerals. Okra traditionally preserved by drying on various surfaces such as the ground, racks, trays and concrete floors. Therefore, an effective means of overcoming the problems of sun drying to dry the okra and other vegetables with solar and hot air dryers. Sun-dried okra then milled into powder prior to use.

(Doymaz, 2005).

Okra is an economically important vegetable crop grown in tropical and sub-tropical parts of the world. This crop is suitable for cultivation as a garden crop as well as on large commercial farms. Okra known by many local names in different parts of the world. It was called lady's finger in England, gumbo in the United States of America, guino-gombo in Spanish, guibeiro in Portuguese, bhindi in India, bamya in some Arabic countries and Turkey (Tripathi et al., 2011). 
(VijayaVenkataRaman et al., 2012) cite that drying is probably the oldest method of food preservation and it is one of the most common processes used to improve food stability. Drying preserves foods by removing enough moisture from food, reduces microbiological activity, and minimizes physical and chemical changes during storage to prevent decay and spoilage

Usually during drying, color may change due to a number of chemical and biochemical reactions (Maskan et al., 2002).

Researchers (Gupta et al., 2002; Hossain and Bala, 2002) reports that, enzymatic browning reaction can prevented by pre-treatment methods, such as blanching and chemical treatment, that inactivates enzyme activity. In fruits and vegetables, enzyme poly phenol oxidase (PPO) can inactivated at temperatures above $60^{\circ} \mathrm{C}$.

Fruit and vegetable products often contain phenolic compounds, which are oxidized and polymerized to form brown pigments, melanin during drying and storage (Perera, 2005).

Color is a perceptual phenomenon that depends on the observer and the conditions in which the color observed. It is a characteristic of light, which is measurable in terms of intensity and wavelength. The color of a material becomes visible only when light from a luminous object or source illuminates or strikes the surface (Sahin and Sumnu, 2006).

Color of agri-food products such as fruit and vegetables was derived from natural pigments, many of which change as the plant proceeds through maturation and ripening. The primary pigments imparting color quality are the fat-soluble chlorophylls (green), carotenoids (yellow, orange, and red), water-soluble anthocyanins (red, blue), flavonoids (yellow) and betalains (red) (Barrett et al. 2010).

Color is one of the most important quality components of fresh fruit and vegetables. Fruit ripening is a complex, genetically programmed process that culminates in dramatic changes in texture, color, flavor and aroma. For instance, the characteristic pigmentation of red, ripe tomato fruit is the result of the de novo synthesis of carotenoids, mainly lycopene and $\beta$ carotene, which are associated with the change in fruit color from green to red as chloroplasts transformed to chromoplasts (Pék et al. 2010). 
Browning in foods is of two types: enzymatic and non-enzymatic. Enzymatic browning is one of the most important reactions that occur in fruits and vegetables, usually resulting in negative effects on color, taste, flavor, and nutritional value. It is a consequence of oxidation reaction of polyphenols catalyzed by polyphenol oxidase enzyme, which facilitate the conversion of phenols to the brown pigment melanin in an oxidation reaction (Guerra et al., 2010).

Other than browning, many reactions can affect color during thermal processing of fruits and vegetables. Among them, the most common is pigment degradation, especially carotenoids and chlorophyll and chemical oxidation of phenols and ascorbic acid. Chemical changes to carotenoids and chlorophyll pigments caused by heat and oxidation during drying. In general, longer drying times and higher drying temperatures produce greater pigment losses. Other factors affecting color include fruit $\mathrm{pH}$, acidity, fruit cultivar and heavy metal contamination (Mongi, 2013).

Firmness of horticulture products, as measured by mechanical methods, frequently used to determine their maturity and ripeness (Deell et al., 2001).

Firmness is one of the major quality indicators of fruit and used as a useful guide for producers, quality inspectors and consumers. Firmness used especially as an indication of the handling characteristics of many fruit, and picking and grading of fruit based on firmness measurements. Traditional destructive methods such as penetrometers or compression tests used to estimate the firmness of fruit. Firmness tests using destructive methods have the advantage of being highly accurate, but the fruit are destroyed and wasted (kim et al., 2009).

Firmness is a good measure of maturity and for many fruit, including apples and pears it used as a measure of eating quality. However, firmness in the laboratory does not translate into good mouth-feel or texture. It is a complex phenomenon based on the physical characteristics of cells. The cell walls of apple and pear flesh are composed of cellulose that provides strength and pectin substances that make contact with adjoining cells and confer flexibility. This flexibility is essential during fruit development as cells expand and fruit grow larger.(Travers, 2013). 
The objective of this research study the effect of different drying methods on some physical and mechanical characteristics of okra pods.

\section{2- MATERIALS AND METHODS.}

\section{1-MATERIALS:-}

\subsection{1-Solar drying systems:}

Four identical solar drying systems designed and manufactured by (Mohamed, et al. 2010) in the Faculty of Agriculture, Menoufia University and installed on the roof of Agricultural Engineering Department at latitude $\left(30^{\circ}\right)$ The main components of each drying systems were (Solar collector, Drying chamber, Drying trays, Chimney) as shown in fig. 1 .

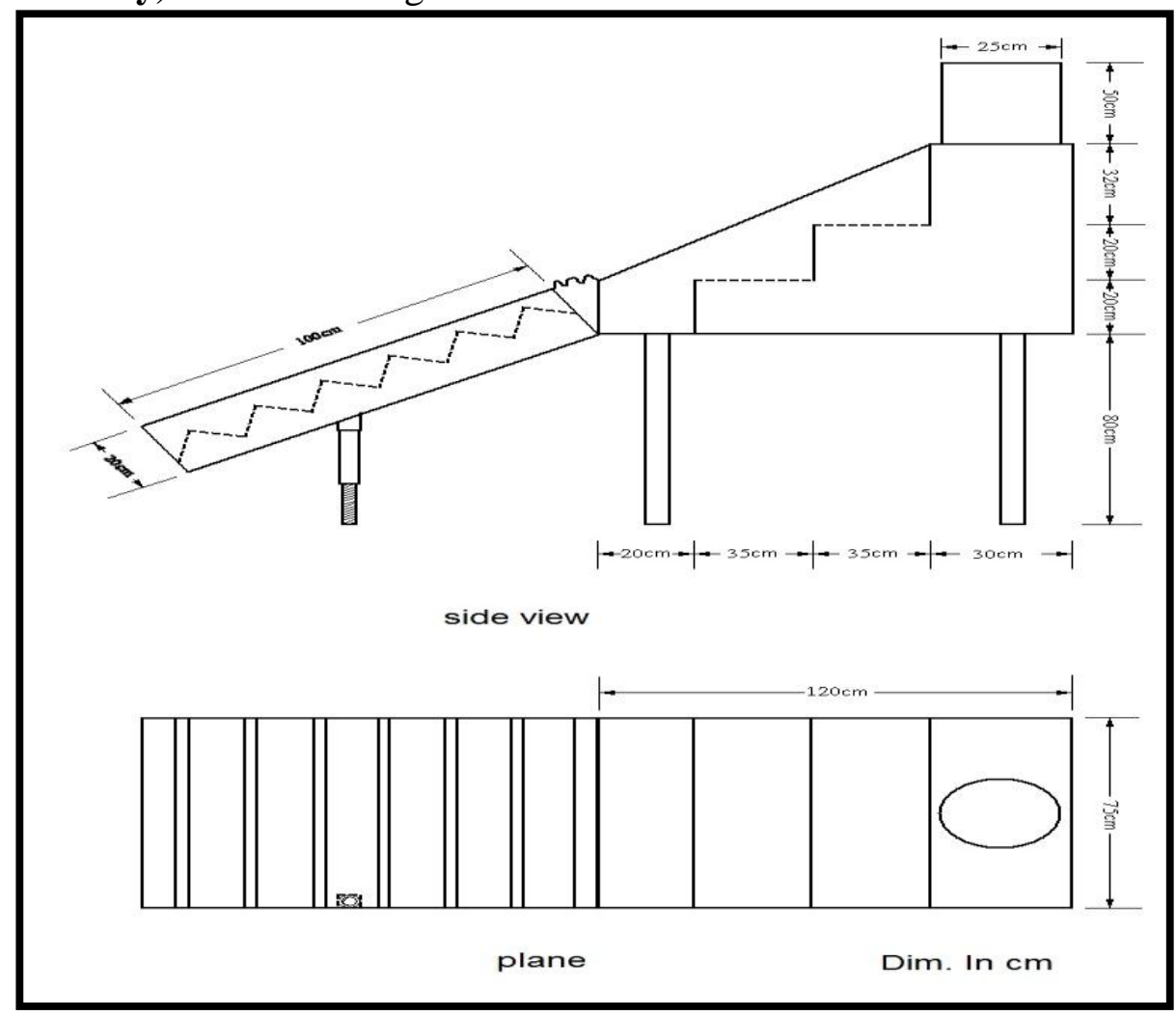

Fig. 1: Schematic diagram of solar drying system (Dim. In cm).

\section{The four solar drying systems illustrated as follow:}

- The Full designed drying system as direct solar dryer with collector fig. 1 (DC).

- The designed drying chamber with glass as direct dryer without 
collector (D).

- The full designed drying system and covered the drying chamber with black plastic sheet as indirect solar dryer (IND).

- Another drying chamber designed in the same sizes the previous, with sides change from wood to glass and the glass thickness in $3 \mathrm{~mm}$ (G).

\subsection{2- Electric thermal oven dryer:}

Table (1) Specifications of electric oven dryer:-

\begin{tabular}{|c|c|}
\hline Country of manufacture & German-made \\
\hline Model & Rumo-10878 \\
\hline Using & Drying experiments. \\
\hline Outside dimensions $\left(\mathbf{W}^{*} \mathbf{H}^{*} \mathbf{D}\right)$ & $\mathbf{8 0} \times \mathbf{7 0} * \mathbf{6 0} \mathbf{c m}$. \\
\hline Cavity Dimensions $\left(\mathbf{W}^{*} \mathbf{H}^{*} \mathbf{D}\right)$ & $\mathbf{5 0} \mathbf{6 0} * \mathbf{5 0} \mathbf{c m}$, \\
\hline Shelves & Three which put the matter on it \\
\hline Input power & $\mathbf{1 5 0 0}$ \\
\hline
\end{tabular}

\subsection{3- Okra:}

Fresh okra (municipal) collected from a private farm at the city Ashmoun, Menoufia. It was stored in the refrigerator at 4 degrees, its length between $30-50 \mathrm{~mm}$, its diameter of between 13-18 $\mathrm{mm}$, and its color was dark green.

\section{2-Measurements:}

\subsection{1-Moisture content:}

The initial moisture content of Okra was determined according to Awady et al., (1993) by drying the products in an electrical oven at $70^{\circ} \mathrm{C}$ for 24 hours.

\subsection{2-Surface colour measurements:}

Surface colour of both fresh and dried apple was measured using a WR10 Colorimeter to obtain the colour values, which measures three parameters: lightness (L), redness (+a) and yellowness (+b), fig. 2. The total colour difference $(\Delta \mathrm{E})$ was then determined using the following equation:

$$
\Delta E=\sqrt{(\Delta L)^{2}+(\Delta a)^{2}+(\Delta b)^{2}}
$$

The fresh okra pods used as the reference and a higher $\Delta \mathrm{E}$ represents greater colour change from the reference material Kamil (2006). Lower $\Delta \mathrm{E}$ show good quality of the Okra pods while the raw Okra pods data tacked as the reference Tark (2007). 


\subsection{3-Firmness:}

Used hardness tester and related penetrometers fig. 3 with quill diameter of $2 \mathrm{~mm}$ pressed ginger slice until the beginning of the break and then take the reading device.

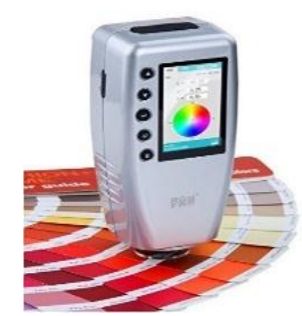

Fig.2: WR10 Portable Colorimeter

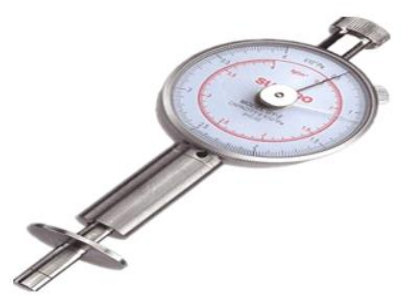

Fig. 3: Photographic of penetrometers.

\subsection{4- Solar Radiation:-}

The solar radiation calculated by mathematical model of (Taha, 2012).

\subsection{5- Temperature and relative humidity:}

The temperature $\left({ }^{\circ} \mathrm{C}\right)$ and air relative humidity (\%) were measured using a Rotronic Instruments UK ltd as shown in fig. 4.

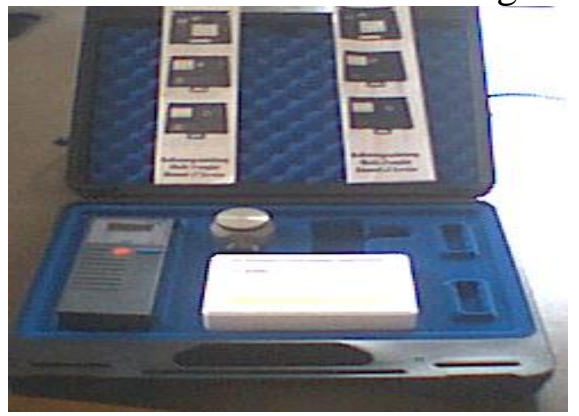

Fig. 4: A Rotronic Instrument measure (Humidity and temperature).

\subsection{6- Energy consumption:-}

Energy consumption measured by energy meter as shown in fig. 5 .

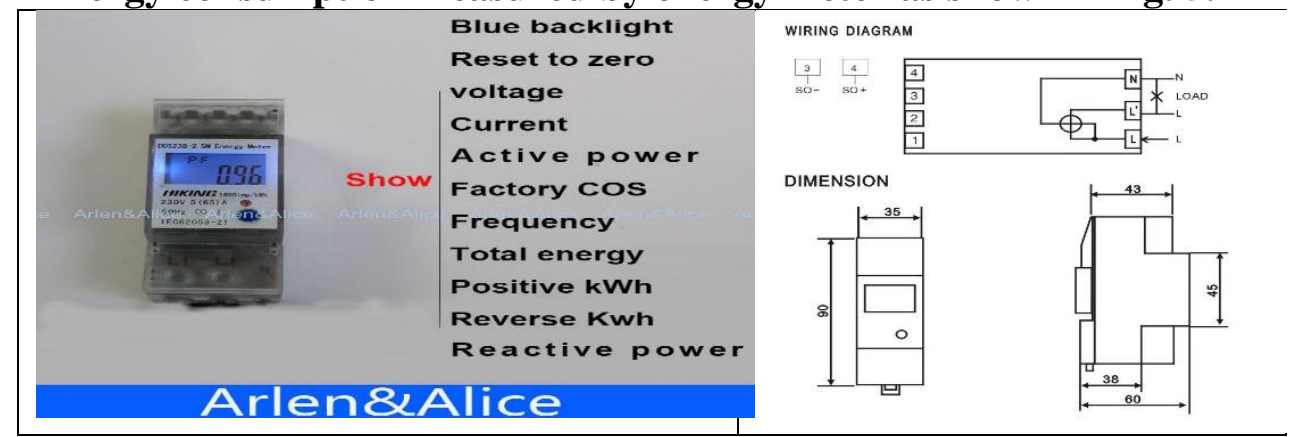

Fig.5: Energy meter. 


\section{3-Experimental procedure:}

The experimental procedures are:

- Okra purchased from a private farm and stored in the refrigerator at a temperature of $4{ }^{\circ} \mathrm{C}$ to next day for conduct the drying operation.

- Okra was treated with a solution of sodium carbonate $1 \%$ for 3 minutes at a temperature of $90^{\circ} \mathrm{c}$. Okra treated and untreated putted in the trays with loading rate of $5 \mathrm{~kg} \mathrm{~m}^{2}$.

- Samples putted in solar dryers from 8 am to $6 \mathrm{pm}$ and the readings tacked every two hours (solar radiation, draying air properties and moisture content of samples).

- At the end of the day, the samples were removed from the dryers, put them in aluminium paper and put it in the middle isolated until the next morning.

- Readings tacked every hour in the drying oven.

- Firmness and colour readings tacked every two hours in the solar drying systems and electric oven dryer.

- Clean the glass of solar drying systems every four hours of the day.

\section{3- RESULTS AND DISCUSSION}

In order to achieve the goals of this research, drying curves and some properties of the products (color and firmness),

\subsection{Effect of drying on okra moisture content:}

The okra pods putted as single layer with loading rate $5 \mathrm{~kg} / \mathrm{cm}^{2}$ at the drying air temperatures of $40,50,60,70$ and $80^{\circ} \mathrm{C}$ in electric oven dryer. Fig. 6 and 7 show the variations in the moisture content as a function with drying time at various drying air temperatures for the treated and untreated okra pods, respectively. From these figures we can be seen that the initial moisture content for treated and untreated okra were 88.9 and $86.1 \%$ (w.b) respectively and decreases continually with drying time. The drying curves presented that, the drying air temperatures and treated okra had a major impact on okra moisture content. In other words, the increase in drying air temperature and treated okra pods resulted that the drying time decreased. 
The drying time to reach the final moisture content for the treated okra pods were $43,28,20,16$, and 12 hour at the drying air temperatures of $40,50,60,70$, and $80^{\circ} \mathrm{C}$, respectively. Corresponding values for the untreated okra pods were 52,33,23, 18, and 13 hour at the drying air temperatures of $40,50,60,70$ and $80{ }^{\circ} \mathrm{C}$, respectively.

Data illustrated that the increasing in air temperatures from $40^{\circ}$ to $80^{\circ} \mathrm{c}$ decreased the drying time by about $72.1 \%, 75 \%$, at the treated and untreated okra pods, respectively.

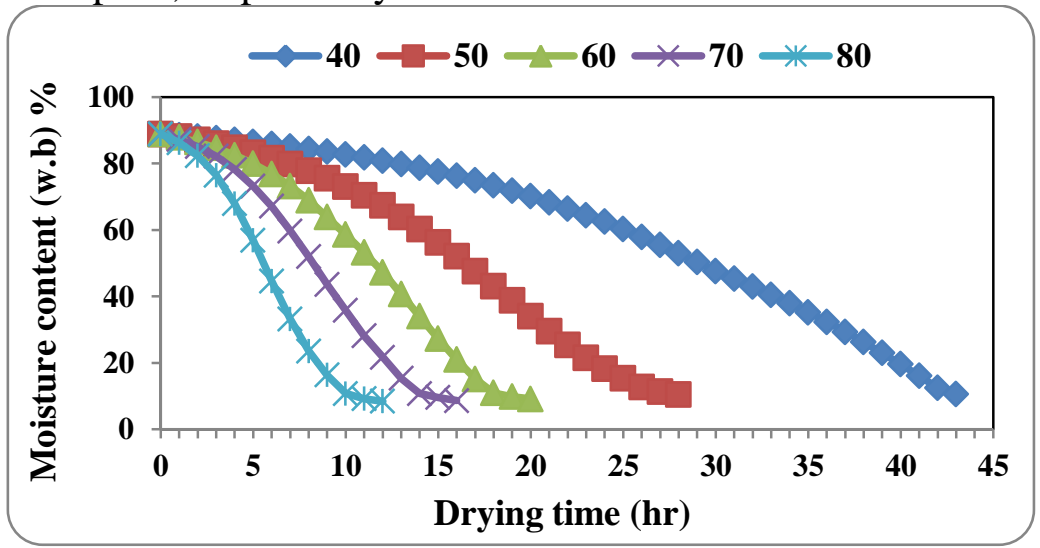

Fig.6: Moisture content of treated okra with drying time at different temperatures.

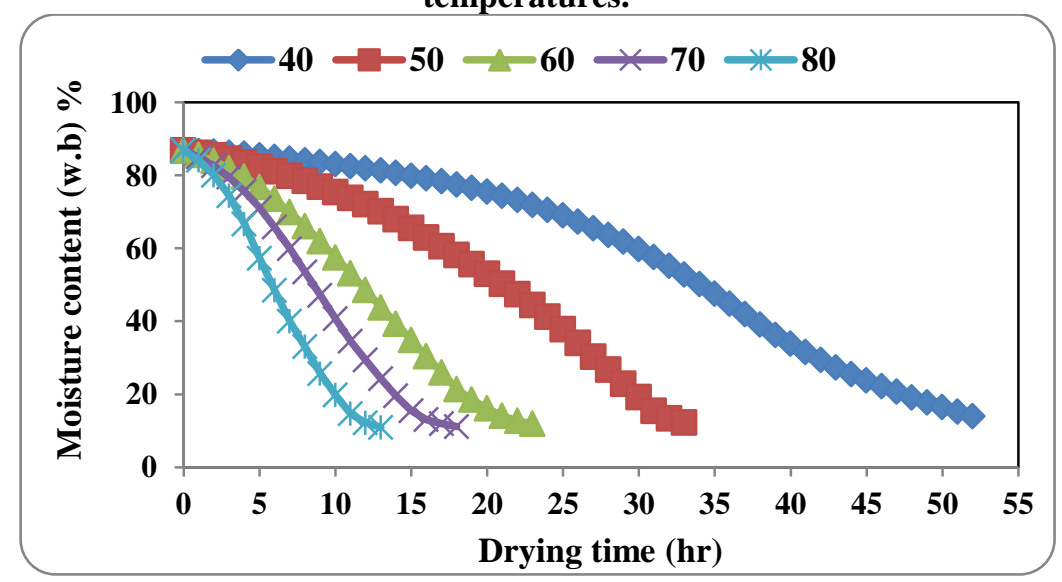

Fig.7: Moisture content of untreated okra with drying time at different temperatures.

The okra pods putted as single layer with loading rate $5 \mathrm{~kg} / \mathrm{cm}^{2}$ in the solar drying systems (direct dryer with solar collector, direct dryer without solar collector, indirect dryer, and glass dryer drying chamber). 
Fig. 8 and 9 describe the variations in the moisture content as a function with drying time in several of solar drying systems. The drying time to reach the final moisture content of treated okra which dried in direct with collector solar dryer was 18 hour and 30 hour for untreated okra, that dried in the same dryer. Corresponding values for the direct without solar collector system were 20 and 34 hour at the treated and untreated okra pods, respectively.

The drying time for the glass dryer chamber were 20 and 32 hour for treated and untreated okra pods, respectively, and the values for the indirect dryer system were 36 and 48 hour for treated and untreated okra pods, respectively.

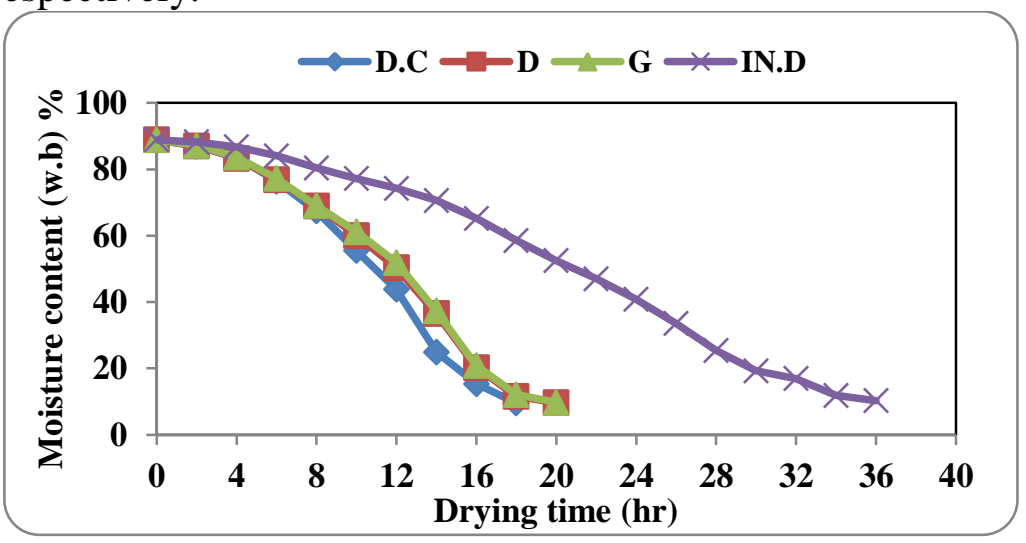

Fig.8: Moisture content of treated okra with drying time in different solar drying systems.

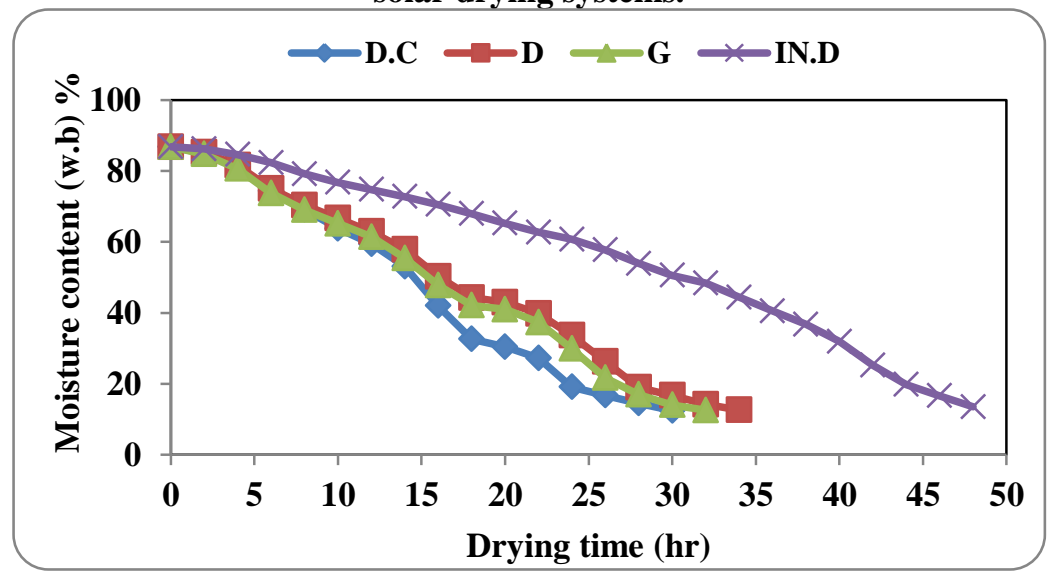

Fig.9: Moisture content of untreated okra with drying time in different solar drying systems. 


\section{2- Energy consumption by okra drying:}

Fig.10 shows consumed energy by treatments of oven drying during drying okra pods. The higher Amount consumption energy was 139.8 MJ at $40^{\circ} \mathrm{c}$ with untreated okra pods and the lowest Amount was $33.3 \mathrm{MJ}$ at $80^{\circ} \mathrm{c}$ with treated okra pods. From this energy consumption increased because of decreasing drying temperature and untreated okra consumed higher than treated okra.

Fig.11 shows consumed energy by treatments of solar drying during drying okra pods. The higher Amount consumption energy was 1.13 MJ at direct with collector drying system with untreated okra pods and the lowest Amount was $0.41 \mathrm{MJ}$ at direct drying system with treated okra pods. From this energy, consumption increased at untreated okra and direct with solar dryer.

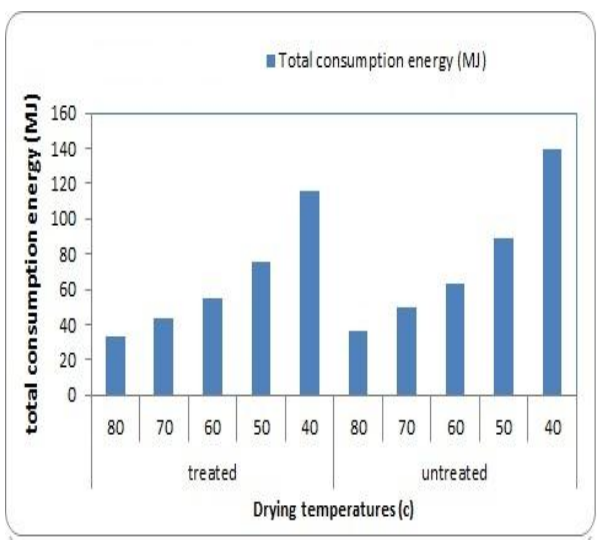

Fig.10: Energy consuming by drying

treated and untreated okra in oven at different temperatures.

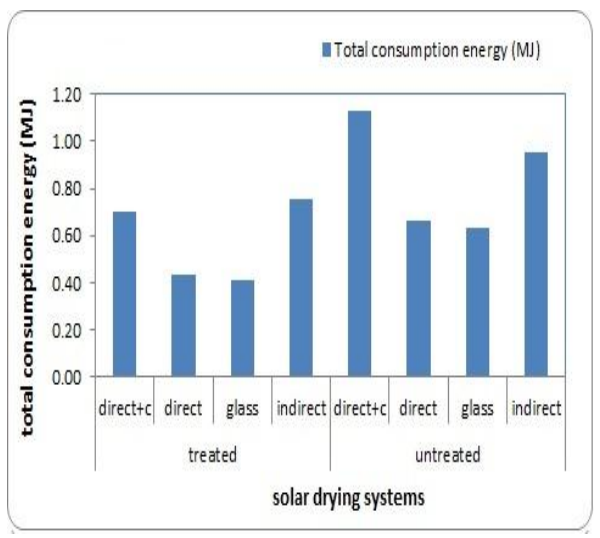

Fig.11: Energy consuming by drying treated and untreated okra in solar drying systems.

\section{3- Okra color properties:}

The color parameters were changes for the fresh sample and the final dried okra for different treatments shown in tables 2 and 3. The $L$ value decreased because of change drying temperatures but it less many at treated okra this indicates that the color tends to blackness color.

While the value of a was changed from negative value for the fresh sample to the positive value when the temperature increased at all 
different temperatures for treated and untreated okra which shows the color change from greenness to redness. This also appears completely at all solar drying systems for treated and untreated okra except treated okra at indirect solar drying system

The value $b$ decreased due to drying temperatures change at treated and untreated okra, and when use different solar drying systems it indicating decreased yellowness color due to the drying process.

\begin{tabular}{|c|c|c|c|c|c|c|c|}
\hline \multicolumn{8}{|c|}{$\begin{array}{c}\text { Table (2): The color parameters for fresh and dried okra in oven } \\
\text { dryer at different drying temperatures. }\end{array}$} \\
\hline & & \multicolumn{3}{|c|}{ treated } & \multicolumn{3}{|c|}{ un treated } \\
\hline & & $\mathbf{L}$ & $\mathbf{a}$ & b & $\mathbf{L}$ & $\mathbf{a}$ & $\mathbf{b}$ \\
\hline \multicolumn{2}{|c|}{ fresh } & 56.3 & -7.5 & 32.7 & 56.3 & -7.5 & 32.7 \\
\hline \multirow{5}{*}{ 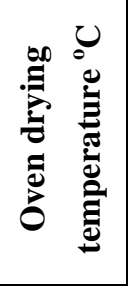 } & 40 & -6.1 & 2.7 & -5.3 & -16.3 & 10.3 & -10.1 \\
\hline & 50 & -4.9 & 3.3 & -7.5 & -17.8 & 11.6 & -12.8 \\
\hline & 60 & -5.9 & 3.2 & -7.8 & -20.9 & 9.7 & -10.3 \\
\hline & 70 & -20.4 & 12.3 & -10.5 & -24.2 & 10.6 & -11.6 \\
\hline & 80 & -22.9 & 12.1 & -11.6 & -25.8 & 9.4 & -14.9 \\
\hline
\end{tabular}

\begin{tabular}{|c|c|c|c|c|c|c|c|}
\hline \multicolumn{8}{|c|}{$\begin{array}{l}\text { Table (3): The color parameters for fresh and dried okra in } \\
\text { different solar drying systems. }\end{array}$} \\
\hline & & \multicolumn{3}{|c|}{ treated } & \multicolumn{3}{|c|}{ un treated } \\
\hline & & $\mathbf{L}$ & $\mathbf{a}$ & b & $\mathbf{L}$ & $\mathbf{a}$ & b \\
\hline \multicolumn{2}{|c|}{ fresh } & 56.3 & -7.5 & 32.7 & 56.3 & -7.5 & 32.7 \\
\hline \multirow{4}{*}{ 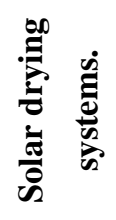 } & DC & -8.1 & 13.1 & -8.1 & -24.3 & 11.6 & -15.1 \\
\hline & D & -11.6 & 7.4 & -8.8 & -22.8 & 13.7 & -12.8 \\
\hline & G & -12.4 & 8.6 & -14.8 & -26.9 & 15.3 & -12.5 \\
\hline & IN.D & -12.1 & 4.1 & -6.8 & -13.4 & 9.6 & -12.8 \\
\hline
\end{tabular}

These changes lead to increase the total color change of untreated okra more than treated okra when drying at 40,50 and $60^{\circ} \mathrm{c}$, while drying at 70 and $80^{\circ} \mathrm{c}$, and at the various solar drying systems as shown in fig. 12 and 13 . 


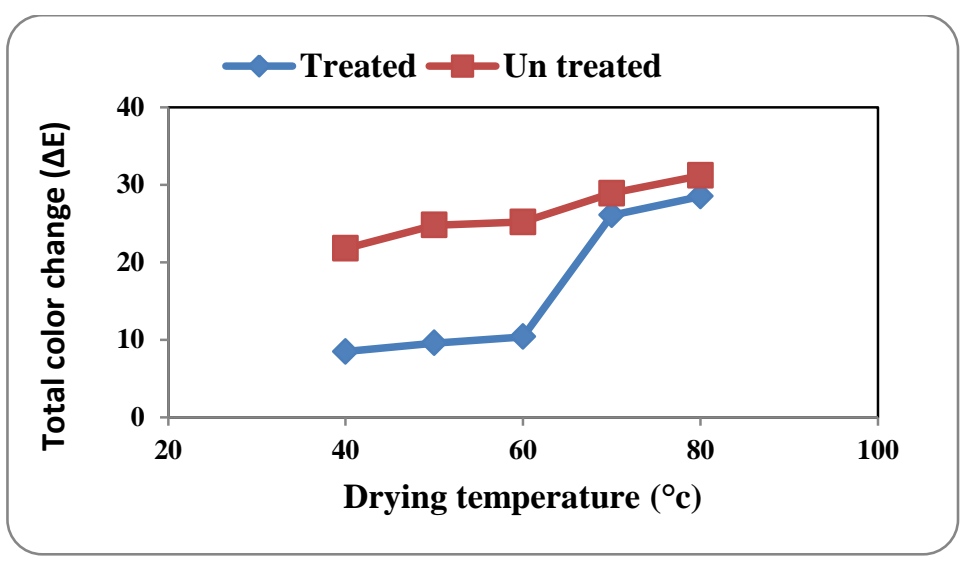

Fig.12: The total color change in okra pods by drying in oven at different

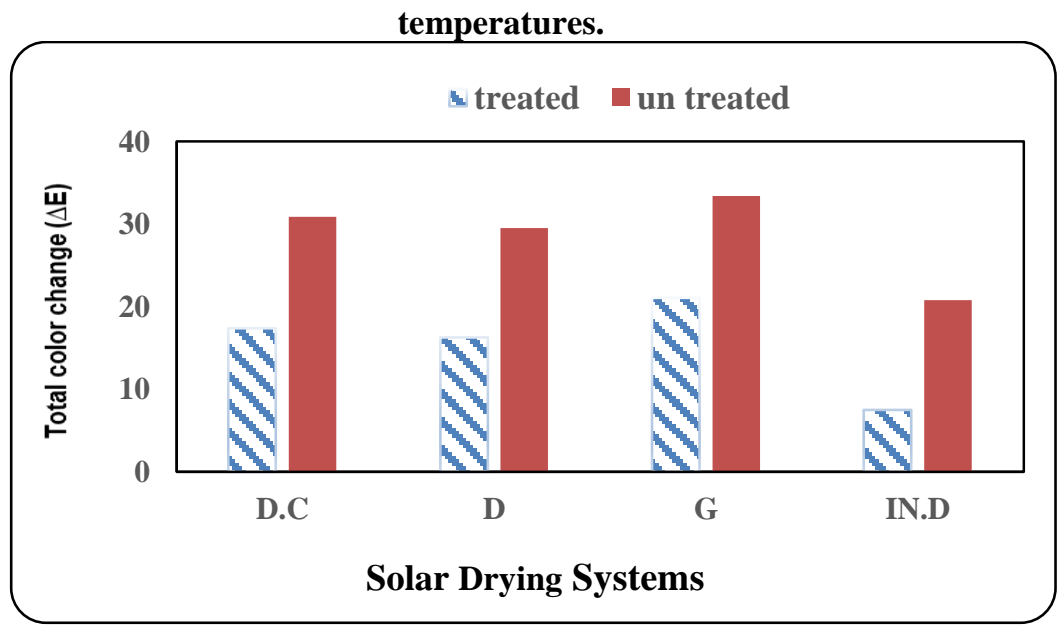

Fig.13 The total color change in okra pods by drying in different solar drying systems.

\section{4- Dried okra firmness:}

The fresh okra firmness ranged between 0.5 to $0.78 \mathrm{~kg} / \mathrm{cm}^{2}$ and then decreased gradually with decrease of moisture content for some time and then it increased even recorded the higher value at the end of the drying time at all drying air temperature in oven drying for untreated okra.

treated okra firmness increased gradually with decrease of moisture content even recorded the higher value at the end of the drying time as show in the table (4) shows the final firmness of okra treated and untreated at all drying air temperature. 
The higher firmness value was $5.94 \mathrm{~kg} / \mathrm{cm}^{2}$ occurred when used the temperature $80^{\circ} \mathrm{c}$ and treated okra and lowest value was $2.67 \mathrm{~kg} / \mathrm{cm}^{2}$ occurred when used the temperature $40^{\circ} \mathrm{c}$ and untreated okra.

When used the treated okra the firmness increase by about $71 \%$ at the drying air temperatures of 40 and $50^{\circ} \mathrm{c}$ and $73 \%, 83 \%$ and $87 \%$ at the drying air temperatures of 60,70 and $80{ }^{\circ} \mathrm{c}$, respectively.

When used the untreated okra the firmness increase by about $89 \%$ at the drying air temperatures of 50,60 and $70^{\circ} \mathrm{c}, 86 \%$ and $91 \%$ at the drying air temperatures of 40 and $80^{\circ} \mathrm{c}$ respectively.

In the solar drying systems the firmness increased gradually with decrease of moisture content even recorded the higher value at the end of the drying time at all solar drying systems at treated and untreated okra as show in the table (5) shows the final firmness of treated and untreated okra at all solar drying systems.

The higher value was $4.11 \mathrm{~kg} / \mathrm{cm}^{2}$ occurred when used the solar drying system (glass drying chamber) and treated okra. The lower value was $3.39 \mathrm{~kg} / \mathrm{cm}^{2}$ occurred when use the solar drying system (indirect) and untreated okra.

When used the treated okra the firmness increase by about $88 \%$ at the solar drying systems (direct with solar collector, direct without solar collector and glass drying chamber) and $83 \%$ at the indirect system.

When used the untreated okra the firmness increase by about $80 \%$ at the solar drying systems (direct with solar collector, direct without solar collector and glass drying chamber) and $77 \%$ at the indirect system.

\begin{tabular}{|c|c|c|}
\hline \multirow{2}{*}{ Table (4): Firmness $\left(\mathrm{kg} / \mathrm{cm}^{2}\right)$} & \multicolumn{2}{|c|}{$\begin{array}{c}\text { of treated and untreated okra dried in oven at different } \\
\text { temperatures: }\end{array}$} \\
\hline drying temperature $\left({ }^{\circ} \mathrm{c}\right)$ & \multicolumn{2}{|c|}{ okra treatments } \\
\cline { 2 - 3 } & treated & un treated \\
\hline \multirow{2}{*}{ Fresh } & 0.50 & 0.78 \\
\hline $40^{\circ}$ & 3.61 & 2.67 \\
\hline $50^{\circ}$ & 4.39 & 2.72 \\
\hline $60^{\circ}$ & 4.50 & 2.94 \\
\hline $70^{\circ}$ & 4.56 & 3.50 \\
\hline $80^{\circ}$ & 5.72 & 4.94 \\
\hline
\end{tabular}




\begin{tabular}{|c|c|c|}
\hline \multicolumn{3}{|c|}{ Table (5): Firmness $\left(\mathrm{kg} / \mathrm{cm}^{2}\right)$ of treated and untreated okra dried in solar drying } \\
systems: \\
\hline solar drying systems & \multicolumn{2}{|c|}{ okra treatments } \\
\cline { 2 - 3 } & treated & un treated \\
\hline fresh & 0.50 & 0.78 \\
\hline DC & 4.00 & 3.78 \\
\hline D & 4.06 & 3.83 \\
\hline G & 4.11 & 3.94 \\
\hline IND & 3.91 & 3.39 \\
\hline
\end{tabular}

\section{4- CONCLUSION:-}

Oven drying at $40^{\circ} \mathrm{C}$ at and indirect solar dryer most effective treatments for drying treated okra it was give the lower value of total color change and higher firmness.

\section{5- REFERENCES}

Akpinar, E. K., Bicer, Y., \& Yildiz, C. (2003). Thin layer drying of red pepper. Journal of Food Engineering, 59(1), 99-104.

\section{Awady, M.N.; S.A. Mohamed; A.S. El-Sayed. and A.A. Hassanain} (1993) "Utilization of solar energy for drying processes of agricultural products". Misr, J. Ag. Eng., 10(4):794-804.

Barrett, D. M., Beaulieu, J. C., \& Shewfelt, R. (2010). Color, flavor, texture, and nutritional quality of fresh-cut fruits and vegetables: desirable levels, instrumental and sensory measurement, and the effects of processing. Critical Reviews in Food Science and Nutrition, 50(5), 369-389.

Bonazzi, C. and Dumoulin, E. (2011). Quality Changes in Food Materials as Influenced by Drying Processes . In: Drying Technology Volume 3: Product Quality and Formulation, First Edition (Edited by Tsotsas, E., Arun, S. and Mujumdar, A.S). Wiley-VCH Verlag GmbH \& Co. KGaA. Published. pp. 1-20.

Boyer, J., \& Liu, R. H. (2004). Review: Apple phytochemicals and their health benefits. Nutrition Journal, 3, 1-15.

Deell, J.R., Khanizadeh, S., Saad, F., Ferree, D.C. (2001). Factors affecting apple fruit firmness: a review. J. Am. Pomol. Soc. 55, 827. 
Doymaz, I., \& Pala, M. (2003). The thin-layer drying characteristics of corn. Journal of Food Engineering, 60, 125-130.

Fellows, J. P. 2000: Food Processing Technology: Cambridge: Wood head Publishing Limited.

Guerra, M. P., Kudo, T., Kon, T. and Holderbaum, D. F. (2010). Enzymatic browning, polyphenol oxidase activity and polyphenols in four apple cultivars: dynamics during fruit development. Hortscience 45(8): 1150 - 1154.

Gupta, P., Ahmed, J., Shivhare, U. S. and Raghavan, G. S. V (2002). Drying characteristics of red chilli. Drying Technology 20(10): 1975 - 1987.

Hossain, M. A. and Bala, B. K. (2002). Thin Layer Drying Characteristics for Green Chilli. Drying Technology 20 (2): 489 505.

Kim, K. B., Kim, M. S., Lee, S., Cho, B.K. (2009). Determination of apple firmness by nondestructive ultrasonic measurement. Postharvest Biology and Technology 52: 44-48.

Lee, K. W., Kim, Y. J., Kim, D. O., Lee, H. J., \& Lee, C. Y. (2003). Major phenolics in apple and their contribution to the total antioxidant capacity. Journal of Agricultural and Food Chemistry, 51, 6516-6520.

Maskan, A., Kaya S., and Maskan, M. (2002). Hot air and sun drying of grape leather (pestil). Journal of Food Engineering 54: 81 - 88.

Mohamed, M. A.; G. R. Gamea; and M. H. Keshek (2010) "Drying characteristics of okra by different solar dryers". Misr J. Ag. Eng. Vol. 27( 1) :294 - 312.

Mongi, R.J. (2013): Solar drying of fruits and vegetables: dryers' thermal performance quality and shelf life of dried mango, banana, pineapple and tomato, Ph.D. Thesis., sokoine university of agriculture. Morogoro, Tanzania.

Pék, Z., Helyes, L., \& Lugasi, A. (2010). Color changes and antioxidant content of vine and postharvest-ripened tomato fruits. HortScience, 45(3), 466-468. 
Perera, C. O. (2005). Selected quality attributed of dried foods. Journal of Drying Technology 23(4): 717 - 730.

Sahin, S., \& Sumnu, S. G. (2006). Physical properties of foods. New York: Springer.

Sinha NK: (2006). Hand book of fruits and fruit processing. USA: Blackwell Publishing; 2006. p. 265-78.

Travers, S., (2013): Dry matter and fruit quality manipulation in the field and evaluation with nir spectroscopy, Ph.D. Thesis., Dept. of Food Science, Faculty of Science and Technology, Aarhus University, Denmark.

UNIDO. (2001a). Quality of dried foods and deteriorative reactions during drying [http://www.unido.org/fileadmin/import/32142_31QualityofDriedF oods.14.pdf].

Velic D, Planinic M, Tomas S, Bilic M (2004). Influence of airflow velocity on kinetics of convection apple drying. Journal of Food Engineering, 64:97-102.

Wang, Z., Sun, J., Liao, X., Chen, F., Zhao, G., Wu, J., Hu, X., (2007). Mathematical modeling on hot air drying of thin layer apple pomace. Food Research International 40 (1), 39-46.

Yaldiz O; Ertekin C (2001). Thin layer solar drying of some vegetables. Drying Technology, 19, 583-596.

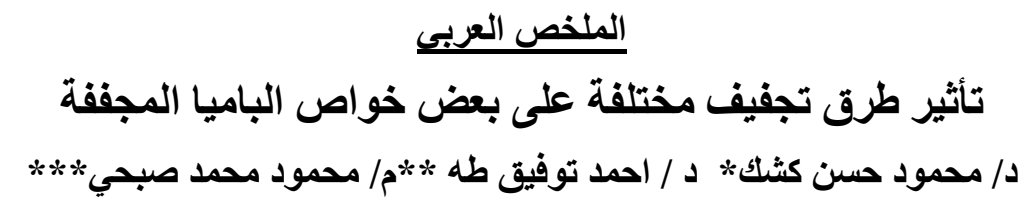

يعتبر التجفيف من الطرق المستخدمة بكثرة في حفظ الخضر و الفاكهة وتعرف عملية التجفيف

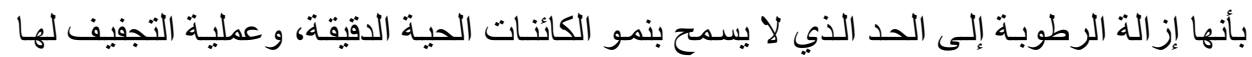

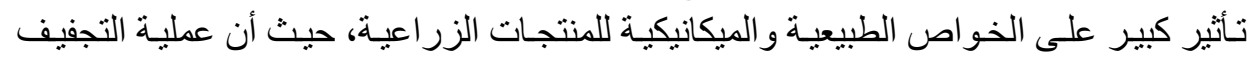

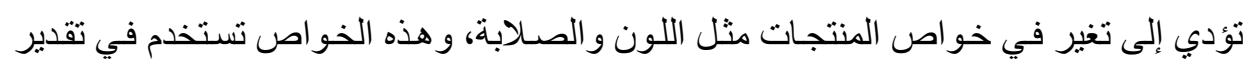
جودة المادة الغذائية المجففة.

* مدرس الهندسة الزراعيةـ قسم الهندسة الزراعية_ كلية الزراعة ـ ـ جامعة المنوفية.

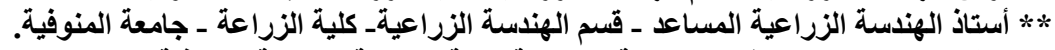

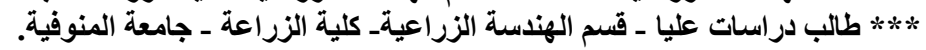


ولتحقيق الهدف من هذا البحث أجريت هذه الدر اسـة بقسم الهندسـة الزر اعيـة ـ كليـة الزر اعـة ــ

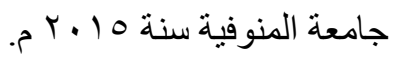

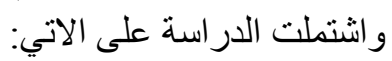

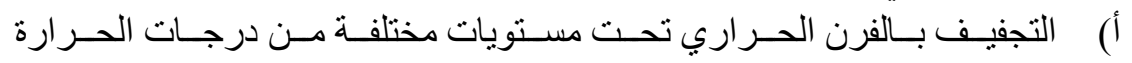

$$
\text { ( ) } \overbrace{}^{\circ} \leqslant \cdot 0 \cdot 67 \cdot 6 \mathrm{~V} \cdot 6 \Lambda \cdot)
$$

$$
\begin{aligned}
& \text { ب) مجف شمسي مباشر ملحق به مجمع شمسي. } \\
& \text { ت) مجفف شمسي مباشر غير ملحق بـه مجمع شمسي. } \\
& \text { ث) مجف شمسي غير مباشر ملحق به مجمع شمسي. مجني. }
\end{aligned}
$$

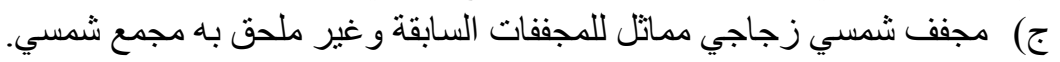

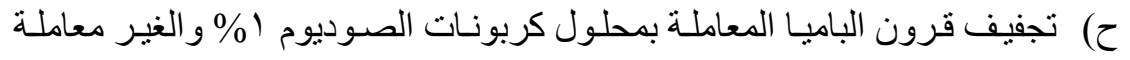
بأنظمة التجفيف المختلفة.

خ) در اسة سلوك منحنيات التجفيف لقرون الباميا تحت أنظمة التجفيف المختلفة.

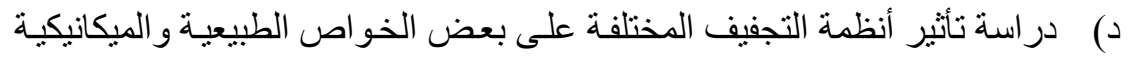

$$
\begin{aligned}
& \text { (اللون - الصلابة) لقرون الباميا. } \\
& \text { وكانت أهم النتائج المتحصل عليها: - }
\end{aligned}
$$

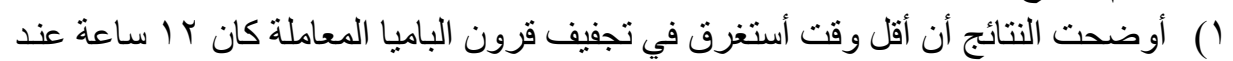

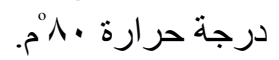

Y) و أوضحت النتائج أن أقل وقت أستغرق في تجفيف قرون الباميا المعاملة كان م ا سـاعة عند

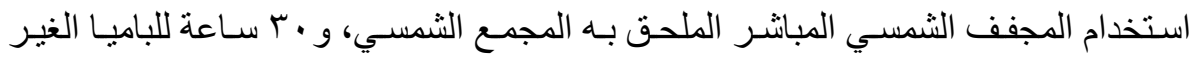

معاملة عند استخدام نفس المجفف.

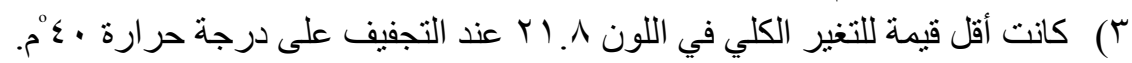
ع) وكانت أقل قيمة للتغير الكلي في اللون ^. • r عند التجفيف باستخدام المجفف الشمسي الغير مباشر.

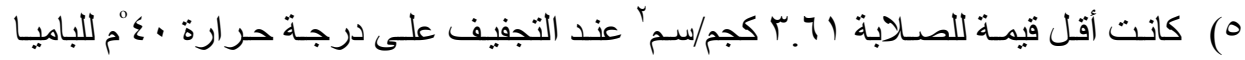

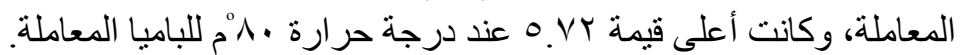

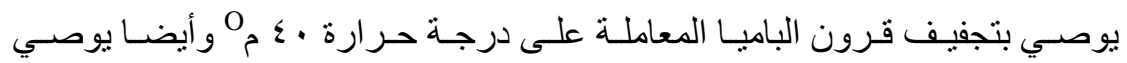

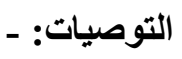
بتجفيف قرون الباميا المعاملة في المجفف الثمسي الغير مباثـر، لأن ذلك يعطي أقل فئل قيمة للتغير اللوني الكلي واعلى الصلابة. 